\title{
Two New Records of Juvenile Oedalechilus labiosus and Ellochelon vaigiensis (Mugiliformes: Mugilidae) from Jeju Island, Korea, as Revealed by Molecular Analysis
}

\author{
Hyuck Joon Kwun, Young Sun Song, Se Hun Myoung and Jin-Koo Kim*
}

Department of Marine Biology, Pukyong National University, Busan 608-737, Korea

\begin{abstract}
Eighteen specimens of juvenile Mugilidae were collected in October 2012 from the southern coastal waters of Jeju Island, and identified based on analysis of their mitochondrial DNA16S rRNA sequences. Seventeen specimens of Oedalechilus labiosus and a single specimen of Ellochelon vaigiensis were found, constituting a new record for these species among Korean ichthyofauna. $O$. labiosus is identified by the angle at the posterior end of its mouth, which contains a round notch, a darkish dorsal margin of the pectoral fin, the presence of 33-36 lateral line scales, and 23-24 vertebrae. E. vaigiensis is identified by dark dorsal and pectoral fins, the presence of 26 lateral line scales, and 25 vertebrae. The proposed Korean name for Oedalechilus is 'Sol-ip-sung-eo-sok' and that for Ellochelon is 'Nup-jeok-ggo-ri-sung-eo-sok.' The proposed Korean names for the species are 'Sol-ip-sung-eo' and 'Nup-jeok-ggo-ri-sung-eo' for O. labiosus and E. vaigiensis, respectively. We present a key for identification of the Mugilidae family of species from Korea, and include these two newly recorded species.
\end{abstract}

Key words: New records, Ellochelon vaigiensis, Oedalechilus labiosus, Mugilidae, Juvenile, 16S rRNA, Jeju Island

\section{Introduction}

Various subtropical fish can be found in the waters surrounding Jeju Island, Korea (Kim and Lee, 1994), and numerous fish previously unrecorded in these waters have recently been reported (Kim, 2009). The family Mugilidae (order Mugiliformes) is widely distributed in tropical and temperate waters, with 72 species divided into 17 genera described worldwide (Nelson, 2006), among which 15 species and 7 genera have been reported from Japan (Senou, 2002). Jordan and Starks (1905) were the first to report the presence of Mugil cephalus Linnaeus 1758 in Korea. Subsequently, Jordan and Metz (1913) and Mori (1952) reported the presence of Chelon haematocheilus (Temminck and Schlegel, 1845) and Chelon affinis (Günther, 1861), respectively. No other species were recorded until 2012, when Chelon macrolepis (Smith, 1846) and
Moolgarda seheli (Forsskål, 1775) were collected near Jeju Island (Kwun et al., 2012a, 2012b), making a total of 5 species and 3 genera reported in Korea to date. Mugilid species are usually identified by their morphological characteristics, including the number of lateral line scales, the location and shape of the maxilla, and the development of the adipose eyelid (Thomson, 1997; Harrison and Senou, 1999; Senou, 2002). However, mugilid species are difficult to identify because their morphological characters are very similar (Thomson, 1997), and thus molecular analysis has recently been applied to the identification of juveniles of the species (Ke et al., 2009; Kwun et al., 2012b). Molecular methods have been used to identify larval and juvenile fish (Kim et al., 2008; Vandersea et al., 2008; Victor et al., 2009; Kwun and Kim, 2010; Kwun et
Open Access http://dx.doi.org/10.5657/FAS.2013.0109

This is an Open Access article distributed under the terms of the Creative Commons Attribution Non-Commercial License (http://creativecommons. org/licenses/by-nc/3.0/) which permits unrestricted non-commercial use, distribution, and reproduction in any medium, provided the original work is properly cited. pISSN: 2234-1749 eISSN: 2234-1757
Received 30 January 2013; Revised 2 April 2013

Accepted 3 April 2013

*Corresponding Author

E-mail: taengko@hanmail.net 
al., 2012b), and have revealed a cryptic fish species (Colborn et al., 2001; Kwun et al., 2011).

In this study, mugilid juveniles were collected by scoop net in October 2012 from the southern coastal waters of Jeju Island. Among the specimens collected, we identified Oedalechilus labiosus (Valenciennes, 1836) and Ellochelon vaigiensis (Quoy and Gaimard, 1825) using molecular methods. Only two species of Oedalechilus Fowler, 1903 and a single species of Ellochelon Whitley, 1930 are recognized worldwide, and none has previously been reported in Korea. In this study, we report two unrecorded mugilid species from Jeju Island.

\section{Materials and Methods}

Eighteen specimens of mugilid juvenile were collected from Yerae Port, Seogwipo, Jeju Island, by scoop net in October 2012, and fixed in 99\% ethanol as whole fish (Table 1). Counts and measurements were carried out according to Thomson (1997) and recorded to the nearest $0.1 \mathrm{~mm}$ using vernier calipers. All fin rays and vertebrae were counted using radiograph images (HA-100; Softex, Tokyo, Japan) and lateral line scales were counted under a stereo microscope (SZX-16; Olympus, Tokyo, Japan). The specimens were kept at the Pukyong National University (PKU) and the National Institute of Biological Resources (NIBR-P), Korea (Table 1).

Genomic DNA extraction and polymerase chain reaction (PCR) for molecular identification were performed according to Kwun and Kim (2010) and Kwun et al. (2012b). Genomic DNA was extracted from muscle tissues using Chelex 100 resin (Bio-Rad, Hercules, CA, USA). PCR was used to amplify the mitochondrial DNA $16 \mathrm{~S}$ rRNA region using a universal primer set (Palumbi, 1996): 16Sar-L (5'-CGCCTGTTTATCAAAAACAT-3'), 16Sbr-H (5'-CCGGTCTGAACTCAGATCACGT-3'). The PCR was conducted using an MJ Mini Thermal Cycler PTC-1148 (Bio-Rad) with the PCR solution containing $10 \mu \mathrm{L}$ of genomic DNA, $5 \mu \mathrm{L}$ of $10 \times$ PCR buffer, $2.4 \mu \mathrm{L}$ of $2.5 \mathrm{mM}$ dNTPs, $1 \mu \mathrm{L}$ of each primer, $0.5 \mu \mathrm{L}$ of FR-Taq polymerase (BioMedics, Seoul, Korea), and distilled water to bring the final volume to $50 \mu \mathrm{L}$. The PCR was car- ried out under the following conditions: initial denaturation at $95^{\circ} \mathrm{C}$ for $5 \mathrm{~min}, 35$ cycles of denaturation at $95^{\circ} \mathrm{C}$ for $1 \mathrm{~min}$, annealing at $50^{\circ} \mathrm{C}$ for $1 \mathrm{~min}$, extension at $72^{\circ} \mathrm{C}$ for $1 \mathrm{~min}$, and a final extension at $72^{\circ} \mathrm{C}$ for $5 \mathrm{~min}$. DNA was sequenced on an ABI 3730XL Sequencer (Applied Biosystems, Foster City, CA, USA) using the ABI PRISM BigDye Terminator v3.1 Ready Reaction Cycle Sequencing Kit (Applied Biosystems). The nucleotide sequences were deposited in the DDBJ/EMBL/ GenBank databases (accession nos. KC741193-KC741194). Sequences were aligned using ClustalW (Thompson et al., 1994) in BioEdit ver. 7 (Hall, 1999), and sequences of $O$. labiosus (JQ060872) and E. vaigiensis (JQ060692) from the National Center for Biological Information (NCBI) database, and C. macrolepis (PKU 7595, KC741195) and M. seheli (PKU 7596, KC741196), were used for molecular comparisons (Table 1). Girella punctata and Terapon jarbua from the NCBI database were selected as outgroups (Table 1). Genetic distances were calculated using the Kimura two-parameter method (Kimura, 1980) and MEGA 5 (Tamura et al., 2011). A neighbor-joining (NJ) tree was constructed with the Kimura two-parameter method (Kimura, 1980) and 10,000 bootstrap replications using MEGA 5 (Tamura et al., 2011).

\section{Results and Discussion}

\section{Oedalechilus Fowler, 1903}

(new Korean name: Sol-ip-sung-eo-sok)

Oedalechilus Fowler, 1903: 748 (type species: Mugil labeo Cuvier, 1829).

Plicomugil Schultz in Schultz, Herald, Lachner, Welander and Woods, 1953: 320 (type species: Mugil labiosus Valenciennes, 1836).

\section{Description}

Preorbital containing deep notch and round posterior tip; slender maxilla, slightly curved downward, and with the posterior tip slightly visible when mouth is closed; upper lip thick and broad, lower lip thin; lip with file-like margins; teeth on

Table 1. List of specimens of the present study

\begin{tabular}{|c|c|c|c|c|c|}
\hline Species & $\begin{array}{l}\text { No. of } \\
\text { specimens }\end{array}$ & Locality & Date & Voucher no. & Accession no. \\
\hline Mugilidae sp. 1 & 16 & Jeju, Jeju-do & 5 Oct 2012 & PKU 7610-7625 & $\begin{array}{l}\text { KC741193 } \\
(\mathrm{PKU} 7610)\end{array}$ \\
\hline Mugilidae sp. 1 & 1 & Jeju, Jeju-do & 5 Oct 2012 & NIBR-P19910 & - \\
\hline Mugilidae sp. 2 & 1 & Jeju, Jeju-do & 5 Oct 2012 & NIBR-P19911 & KC741194 \\
\hline Chelon macrolepis & 1 & Jeju, Jeju-do & 5 Oct 2012 & PKU 7595 & KC741195 \\
\hline Moolgarda seheli & 1 & Jeju, Jeju-do & 5 Oct 2012 & PKU 7596 & KC741196 \\
\hline Girella punctata & 1 & $\begin{array}{l}\text { Goseong, } \\
\text { Gyeongsangnam-do }\end{array}$ & 29 Nov 2008 & PKU 1160 & HQ018813 \\
\hline Terapon jarbua & 1 & Jeju, Jeju-do & $1 \mathrm{Jul} 2011$ & PKU 6485 & JQ178232 \\
\hline
\end{tabular}




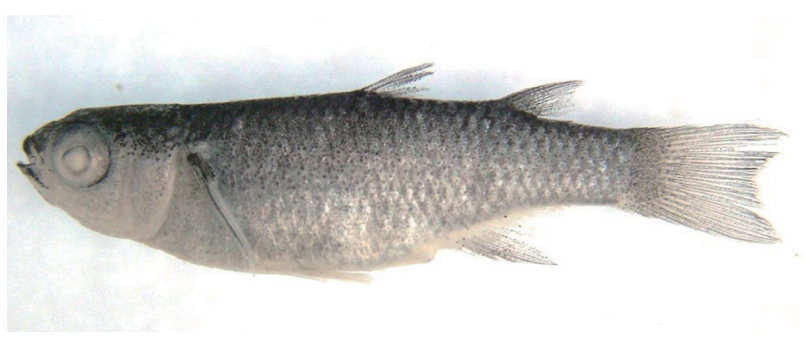

Fig. 1. Oedalechilus labiosus, PKU 7610 (27.5 mm standard length) collected from the southern waters of Jeju Island.

vomer and palatines; interorbital region slightly convex; adipose eyelid poorly developed; no spine on the margin of the operculum; pectoral fin length slightly longer than the head length; axillary scale small; caudal fin forked or emarginated; body covered with cycloid scales; 32-52 lateral line scales (Schultz et al., 1953; Thomson, 1997; Harrison and Senou, 1999).

\section{Remarks}

Only two species, Oedalechilus labeo and O. labiosus, have been reported in the genus Oedalechilus, and they are distinguishable by the number of lateral line scales (48-52 in O. labeo vs. 32-37 in O. labiosus) and their distributions (Mediterranean Sea for $O$. labeo vs. the Indo-Pacific Ocean for O. labiosus) (Thomson, 1997; Harrison and Senou, 1999).

\section{Oedalechilus Iabiosus (Valenciennes, 1836) (Table 2, Fig. 1)}

(new Korean name: Sol-ip-sung-eo)

Mugil labiosus Valenciennes in Cuvier and Valenciennes, 1836: 125 (type locality: Red Sea).

Mugil joloensis Seale, 1910: 500 (type locality: Philippines).

Oedalechilus labiosus: Thomson, 1997: 543; Harrison and Senou, 1999: 2100; Randall and Lim, 2000: 625; Shen, 2001: 440; Senou, 2002: 537.
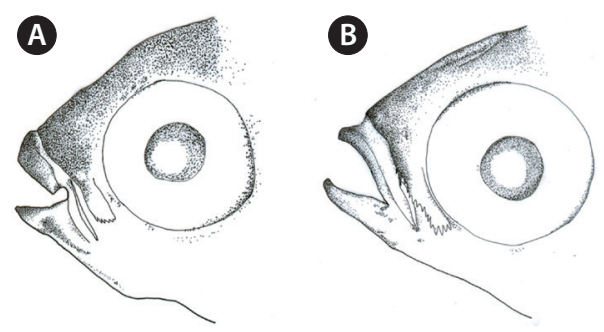

Fig. 2. Illustration of head of two Mugilidae species. (A) Oedalechilus labiosus, PKU 7610 and (B) Ellochelon vaigiensis, NIBR-P19911.

\section{Material examined}

PKU 7610-7625, 16 specimens, 23.0-29.1 mm standard length (SL); NIBR-P19910, 1 specimen, $26.7 \mathrm{~mm} \mathrm{SL}$, Yerae Port, Seogwipo, Jeju Island, Scoop net, 5 Oct 2012 (Fig. 1).

\section{Description}

Counts are shown in Table 2. Measurements, expressed as a percentage (mean in parentheses) of the SL, include the following: body depth 24.5-29.2 (27.9); head length 26.6-30.9 (28.9); head width 16.1-19.4 (17.7); snout length 6.5-8.0 (7.2); interorbital width 11.5-15.0 (13.6); eye diameter 9.1-11.2 (10.0); upper lip height 1.7-2.6 (2.2); predorsal length 53.362.3 (57.6); pectoral fin length 20.0-23.3 (22.0); and caudal peduncle depth 11.7-12.8 (12.3).

Head broad, and depressed dorsally; body deep and compressed posteriorly; mouth terminal; posterior tip of maxilla beyond the anterior margin of the eye; symphysis blunt; posterior margin of preorbital with 5-6 spines (Fig. 2A); upper lip thicker than lower lip; posterior end of mouth angle with round notch (Fig. 2A); posterior tip of maxilla beyond mouth angle; 1 or 2 rows of curved conical teeth on each jaw; snout short and blunt; interorbital region slightly convex; adipose eyelid absent; 2 dorsal fins completely separated, and origin of 1st dorsal fin located in the middle of the body; posterior tip of pectoral fin extending beyond the vertical line from the origin of the pelvic fin, and posterior tip of the pelvic fin extending beyond the vertical line from the origin of the 1st dorsal fin;

Table 2. Comparison of meristic characters of Oedalechilus labiosus and Ellochelon vaigiensis

\begin{tabular}{|c|c|c|c|c|c|c|}
\hline & \multicolumn{3}{|c|}{ Oedalechilus labiosus } & \multicolumn{3}{|c|}{ Ellochelon vaigiensis } \\
\hline & Present study & $\begin{array}{c}\text { Thomson } \\
\text { (1997) }\end{array}$ & $\begin{array}{l}\text { Harrison and } \\
\text { Senou (1999) }\end{array}$ & Present study & $\begin{array}{c}\text { Thomson } \\
\text { (1997) }\end{array}$ & $\begin{array}{l}\text { Harrison and } \\
\text { Senou (1999) }\end{array}$ \\
\hline No. of specimens & 17 & 22 & - & 1 & 72 & - \\
\hline Standard length $(\mathrm{mm})$ & $23.0-29.1$ & $61-180$ & - & 16.7 & $10-75$ & - \\
\hline Dorsal fin rays & IV-8-9 & IV-I, 8 & IV-9 & IV-8 & IV-i-8 & IV-9 \\
\hline Anal fin rays & III, 8-9 & III, 9 & III, 9 & III, 8 & III, 8 & III, 7-9 \\
\hline Vertebrae & $23-24$ & - & - & 25 & - & - \\
\hline Lateral line scales & $33-36$ & $34-36$ & $32-37$ & 26 & $24-26$ & $25-29$ \\
\hline Transverse scales & $11-12$ & 12 & $11-12$ & 9 & 8 & $8-10$ \\
\hline
\end{tabular}




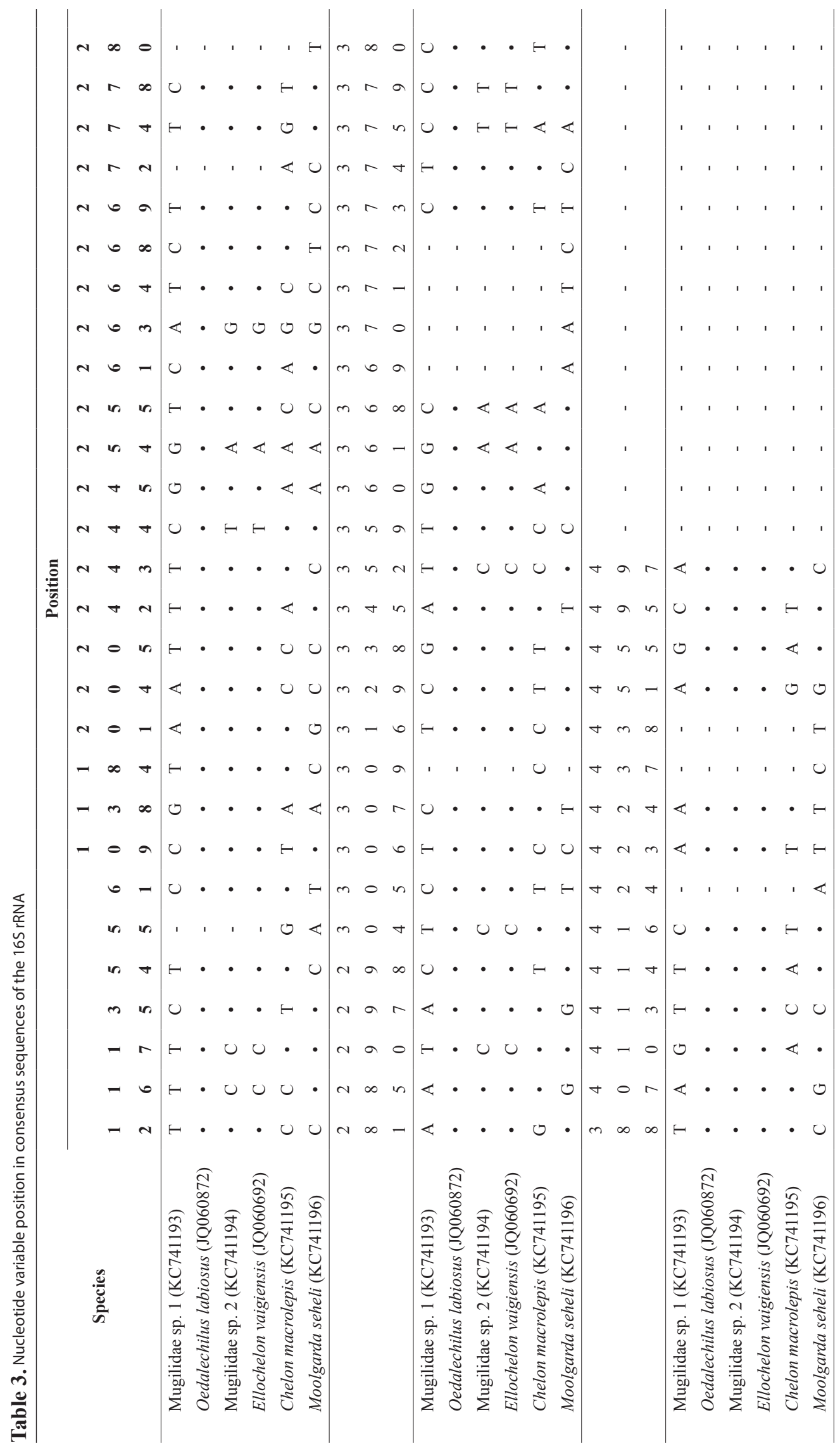




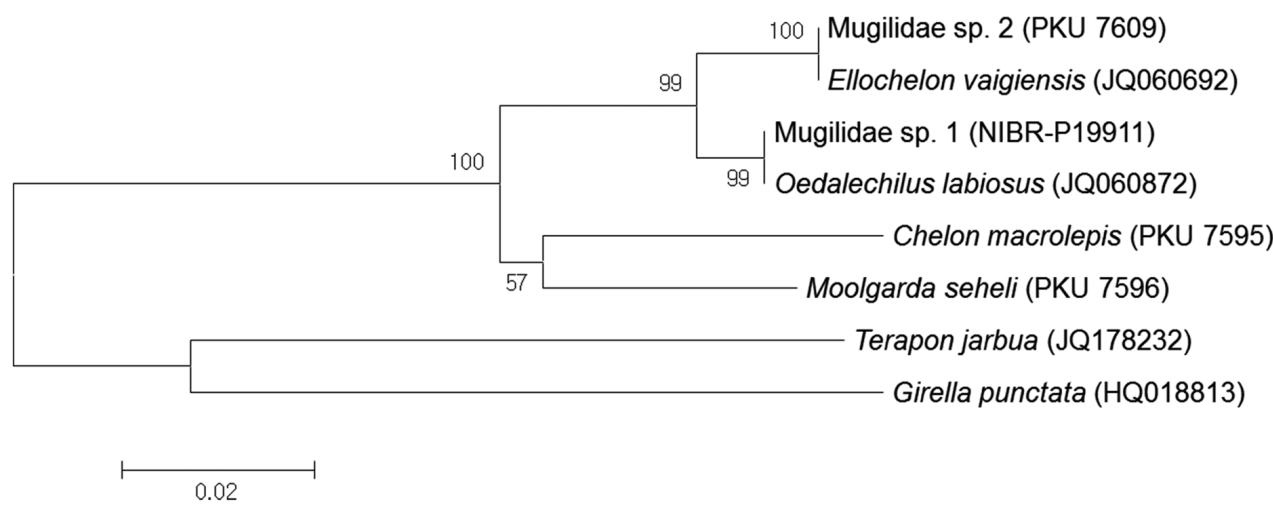

Fig. 3. Neighbor joining tree showing the relationships among four mugilids species including two mugilids juveniles (Mugilidae sp. 1 and 2). Terapon jarbua and Girella punctata are outgroups. Numbers at branches indicate bootstrap probabilities in 10,000 bootstrap replications. Bar indicates genetic distance of 0.02 .

origin of the anal fin located in front of the vertical line from the origin of the 2nd dorsal fin; pectoral fin with small axillary scales; caudal fin emarginated; head and body covered with cycloid scales.

\section{Coloration}

When fresh, the head and body are silver-whit, darkening dorsally. Both lips are dark. All fins are semitransparent. Tiny melanophores are present on the membranes of the dorsal, caudal, and anterior region of anal fins, with no melanophores on the pelvic fin. Dorsally, the margin of the pectoral fin is dark. After alcohol fixation, the head and body turned a darker silver-white.

\section{Molecular identification}

Based on analysis of a 592-base pair (bp) mitochondrial DNA $16 \mathrm{~S}$ rRNA sequence, Mugilidae sp. 1 corresponds to $O$. labiosus at a genetic distance of 0.000 , but differs from Mugilidae sp. 2 and E. vaigiensis with a genetic distance of 0.020 , $M$. seheli at 0.058 , and C. macrolepis at 0.068 . The differences are shown as DNA variations between position numbers 12 and 497 (Table 3). In the NJ tree, Mugilidae sp. 1 clustered with $O$. labiosus, which was corroborated by a high bootstrap value of $99 \%$ (Fig. 3).

\section{Distribution}

Oedalechilus labiosus is distributed throughout the IndoPacific Ocean including the Red Sea (Thomson, 1997; Harrison and Senou, 1999), Japan (Senou, 2002), Taiwan (Shen, 2001), the South China Sea (Randall and Lim, 2000), and the Philippines (Seale, 1910). In Korea it occurs in the southern waters of Jeju Island (found in this study).

\section{Remarks}

Based on the original description of O. labiosus (Cuvier and Valenciennes, 1836), the 17 specimens of Mugilidae sp.
1 collected from the southern waters of Jeju Island closely resemble this species, notably in having a deep body and an exposed posterior tip of the maxilla, and in the number of dorsal and anal fin rays. They also have a mouth angle with a round notch and 33-36 lateral line scales (Harrison and Senou, 1999; Senou, 2002), just like O. labiosus. According to the NCBI database, they had $100 \%$ sequence identity with sequences of O. labiosus. Therefore, our specimens were identified as $O$. labiosus based on both morphological and molecular evidence. The adult stage of $O$. labiosus has lips with file-like margins, and the ventral margin of the preorbital has a deep V-shaped notch, but these features were not evident in our juvenile specimens; this difference in morphological characteristics may be a consequence of ontogenetic variation. This characteristic is important in distinguishing the species from the five other mugilid species reported from Korea (i.e., file-like lips in O. labiosus vs. smooth in the five mugilid species) (Senou, 2002). We propose a Korean name of 'Sol-ip-sung-eo-sok' for the genus Oedalechilus and 'Sol-ip-sung-eo' for O. labiosus.

\section{Ellochelon Whitley, 1930}

(new Korean name: Nup-jeok-ggo-ri-sung-eo-sok)

Ellochelon Whitley, 1930: 251 (type species: Mugil vaigiensis Quoy and Gaimard, 1825).

\section{Description}

Posterior tip of preorbital broad and square; maxilla slender, curved downward, and the posterior tip visible when mouth is closed; lips thin; lower margin of upper lip smooth; teeth on vomer and palatines; interorbital region slightly convex; adipose eyelid poorly developed; caudal fin truncated; body covered with ctenoid scales (cycloid in juvenile); 24-29 lateral line scales; pectoral fin black (Thomson, 1997; Harrison and Senou, 1999; Senou, 2002). 


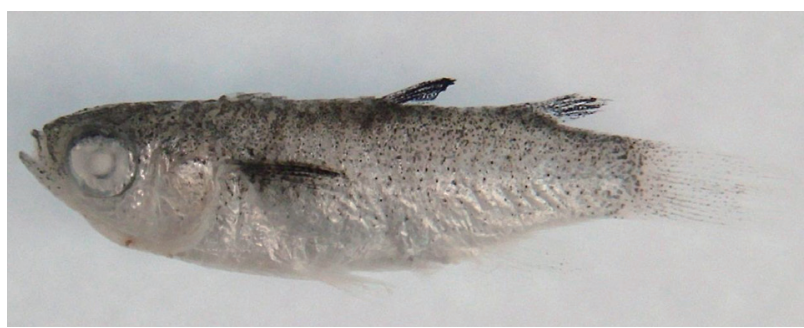

Fig. 4. Ellochelon vaigiensis, NIBR-P19911 (16.7 mm standard length) collected from the southern waters of Jeju Island.

\section{Remarks}

Only one species, E. vaigiensis, is recorded in the genus Ellochelon (Eschmeyer, 2012), which differs from the genus Chelon in pectoral fin coloration (black in the former vs. not black in the latter) and caudal fin shape (truncated vs. forked) (Senou, 2002).

\section{Ellochelon vaigiensis (Quoy and Gaimard, 1825) (Table 2, Fig. 4)}

(Korean name: Nup-jeok-ggo-ri-sung-eo)

Mugil vaigiensis Quoy and Gaimard, 1825: 337 (type locality: Indonesia).

Mugil melanochir Valenciennes in Cuvier and Valenciennes, 1836: 143 (type locality: Indonesia).

Liza vaigiensis: Thomson, 1997: 537; Harrison and Senou, 1999: 2094; Kim et al., 2010: 143.

Ellochelon vaigiensis: Whitley, 1930: 250; Randall and Lim, 2000: 625; Senou, 2002: 537; Motomura et al., 2010: 79.

\section{Material examined}

NIBR-P19911, 1 specimen, 16.7 mm SL, Yerae Port, Seogwipo, Jeju Island, Scoop net, 5 Oct 2012 (Fig. 3).

\section{Description}

Counts are shown in Table 2. Measurements, expressed as a percentage of the SL, include: body depth 28.7; head length 32.9; head width 19.2; snout length 8.4 ; interorbital width 15.6; eye diameter 10.8; upper lip height 1.8 ; predorsal length 58.7; pectoral fin length 12.6; and caudal peduncle depth 18.0.

Head broad and depressed dorsally; body deep and compressed posteriorly; mouth terminal, with posterior tip of the maxilla reaching to the anterior margin of the eye; symphysis slightly pointed; posteroventral margin of the preorbital with numerous spines (Fig. 2B); both lips thin; posterior tip of the maxilla beyond the mouth angle; 1-2 rows of curved conical teeth on each jaw; snout short and slightly pointed; interorbital region slightly convex; adipose eyelid absent; 2 dorsal fins completely separated, and origin of the 1 st dorsal fin located behind the midline of the body; posterior tip of the pectoral fin beyond a vertical line at the origin of the pelvic fin, and posterior tip of pelvic fin beyond a vertical line at the origin of the 1st dorsal fin; origin of anal fin located in front of a vertical line at the origin of the 2nd dorsal fin; pectoral fin without axillary scales; caudal fin truncated; head and body covered with cycloid scales.

\section{Coloration}

When fresh, the head and body are silver-white and darkish yellow dorsally. Both lips are dark. The dorsal and pectoral fins are black, and the pelvic, anal, and caudal fins are semitransparent. The pelvic and anal fins are yellowish; the caudal fin is light yellow, with tiny melanophores on the membrane. After alcohol fixation, the head and body were darkish silverwhite; and the yellow color of the pelvic, anal, and caudal fins graded to colorless.

\section{Molecular identification}

Based on analysis of a 592-bp mitochondrial DNA 16S rRNA sequence, Mugilidae sp. 2 corresponded to E. vaigiensis at a genetic distance of 0.000 , and differed from Mugilidae sp. 1 and $O$. labiosus at a distance of 0.020, C. macrolepis at 0.068 , and $M$. seheli at 0.071 . Their differences were shown by DNA variations between positions 12 and 497 (Table 3). In the NJ-tree, Mugilidae sp. 2 clustered with E. vaigiensis, which was corroborated by a high bootstrap value of $100 \%$ (Fig. 3).

\section{Distribution}

Ellochelon vaigiensis is distributed throughout the IndoPacific Ocean (Thomson, 1997; Harrison and Senou, 1999), Japan (Senou, 2002; Motomura et al., 2010), the South China Sea (Randall and Lim, 2000), and Indonesia (Quoy and Gaimard, 1825; Cuvier and Valenciennes, 1836). In Korea, the species occurs in the southern waters of Jeju Island (this study).

\section{Remarks}

Based on the original description of E. vaigiensis (Quoy and Gaimard, 1825), the single specimen of Mugilidae sp. 2 collected from the southern waters of Jeju Island matches this species, having a smooth lip margin, the same coloration, and number of dorsal and anal fin rays. It has a black pectoral fin and 26 lateral line scales, also consistent with E. vaigiensis (Harrison and Senou, 1999; Senou, 2002). We found that the specimen had $100 \%$ sequence identity with $E$. vaigiensis sequences on the NCBI database. Our specimen was therefore identified as E. vaigiensis, based on both morphological and molecular evidence. Comparison of E. vaigiensis with the five mugilid species reported from Korea indicate that the species differs in the color of the pectoral fin (black in E. vaigiensis vs. light or dark gray in the five mugilid species) and the shape of the caudal fin (truncated in E. vaigiensis vs. forked or emarginated in the five mugilid species) (Senou, 2002). We propose the Korean names 'Nup-jeok-ggo-ri-sung-eo-sok' for the genus Ellochelon and 'Nup-jeok-ggo-ri-sung-eo' for E. 
vaigiensis, following Kim et al. (2010).

\section{Key to the species of family Mugilidae from Korea}

1a. Posterior end of mouth angle with round notch. Margin of upper lip with file-like except during early life stage. …...... Sol-ip-sung-eo (new Korean name) Oedalechilus labiosus

1b. Posterior end of mouth angle without round notch. margin of upper lip smooth. ………........................................ 2

2a. Pectoral fin black. Caudal fin truncate.

- Nup-jeok-ggo-ri-sung-eo Ellochelon vaigiensis

2b. Pectoral fin light or dark gray. Caudal fin emarginate or forked. ... 3

3a. Posterior end of maxilla reaching to mouth angle Sung-eo Mugil cephalus

3b. Posterior end of maxilla beyond mouth angle. ……....... 4

4a. Posterior margin of scales on middle of body with membrane. When mouth closed, posterior tip of maxilla not exposed or slightly visible.

Cho-seung-ggo-ri-sung-eo Moolgarda seheli

4b. Posterior margin of scales on middle of body without membrane. When mouth closed, posterior tip of maxilla exposed.

.. 5

5a. Keel in front of dorsal fin.

. Deung-jul-sung-eo Chelon affinis

5b. No keel in front of dorsal fin.

6a. Lateral line scales 30-34.

Keun-bi-neul-sung-eo Chelon macrolepis

6b. Lateral line scales $38-44$.

Ga-sung-eo Chelon haematocheilus

\section{Acknowledgements}

This research was supported by the project on survey and excavation of Korean indigenous species of the National Institute of Biological Resources (NIBR) under the Ministry of Environment, Korea.

\section{References}

Colborn J, Crabtree RE, Shaklee JB, Pfeiler E and Bowen BW. 2001. The evolutionary enigma of bonefishes (Albula spp.): cryptic species and ancient separations in a globally distributed shorefish. Evolution 55, 807-820.

Cuvier G. 1829. Le Règne Animal, Distribué Daprès Son Organization: Pour de Base à l'Histoire Naturelle des Animaux et d'Introduction à l'Anatomie Compare. Vol. 2. Chez Déterville, Paris, FR.

Cuvier G and Valenciennes A. 1836. Histoire Naturelle des Poissons. Tome Onzième. Livre Treizième. De la Famille des Mugiloïdes. Livre Quatorzième. De la Famille des Gobioïdes. Vol. 11. Même maison, Strasbourg, FR.

Eschmeyer WN. 2012. Catalog of fishes [Internet]. California Academy of Sciences, CA, US, Accessed 1 Nov 2012, http://research. calacademy.org/research/ichthyology/catalog/fishcatmain.asp.

Forsskål PS. 1775. Descriptiones Animalium Avium, Amphibiorum, Piscium, Insectorum, Vermium; Quae in Itinere Orientali Observavit Petrus Forskål. Post Mortem Auctoris Edidit Carsten Niebuhr. XXXIV. Adjuncta est Medica Kahirina atque Tabula Maris Rubri Geographica. Ex Officina Mölleri, Hauniæ, DK.

Fowler HW. 1903. Descriptions of new, little known, and typical Atherinidae. Proc Acad Nat Sci Phila 55, 727-742.

Günther A. 1861. Catalogue of the Fishes in the British Museum. Catalogue of the Fishes in the British Museum. Vol. 3. Acanthopterygian Fishes: Gobiide to Notacanthi. British Museum, London, GB.

Hall TA. 1999. BioEdit: a user-friendly biological sequence alignment editor and analysis program for Windows 95/98/NT. Nucl Acids Symp Ser 41, 95-98.

Harrison IJ and Senou H. 1999. Mugilidae. In: FAO Species Identification Guide for Fishery Purposes. The Living Marine Resources of the Western Central Pacific. Vol. 4. Bony Fishes. Part 2 (Mugilidae to Carangidae). Carpenter KE and Niem VH, eds. FAO, Rome, IT, pp. 2069-2108

Jordan DS and Metz CW. 1913. A catalog of the fishes known from the waters of Korea. Mem Carnegie Mus 6, 1-65.

Jordan DS and Starks EC. 1905. On a collection of fishes made in Korea, by Pierre Louis Jouy, with descriptions of new species. Proc U S Natl Mus 28, 193-212.

Ke HM, Lin WW and Kao HW. 2009. Genetic diversity and differentiation of gray mullet (Mugil cephalus) in the coastal waters of Taiwan. Zoolog Sci 26, 421-428.

Kim BJ, Kim S, Seo HS and Oh J. 2008. Identification of Albula sp. (Albulidae: Albuliformes) leptocephalus collected from the southern coastal waters of Korea using cytochrome $b$ DNA sequences. Ocean Sci J 43, 101-106.

Kim IS and Lee WO. 1994. Fish Fauna from Cheju Island, Korea, Records of Korean Fish Fauna No. 1. Department of Ecology, Chonbuk Natational University, Iksan, KR.

Kim JB, Kim DN, Kim JK, Ryu JH, Park JH, Hwang SJ, An DH, Lee DW, Kim ZG, Seok KJ, Oh TY, Moon DY, Kim YS, Kim YU, Jo SH and Choi SG. 2010. Fishes of the Ocean. Hangeul Graphics, Busan, KR (in Korean).

Kim JK. 2009. Diversity and conservation of Korean marine. Korean J Ichthyol 21(Suppl 1), 52-62.

Kimura M. 1980. A simple method for estimating evolutionary rates of base substitutions through comparative studies of nucleotide sequences. J Mol Evol 16, 111-120.

Kwun HJ and Kim JK. 2010. Validation of morphology-based identification of two Cynoglossidae larvae using mitochondrial DNA. Korean J Fish Aquat Sci 43, 482-488 (in Korean).

Kwun HJ, Kim JK, Doiuchi R and Nakabo T. 2011. Molecular and morphological evidence for the taxonomic status of a newly reported species of Albula (Albuliformes: Albulidae) from Korea and Taiwan. Anim Cells Syst 15, 45-51.

Kwun HJ, Kim BJ, Lee CS, Lee CL and Kim JK. 2012a. First record of largescale mullet, Chelon macrolepis (Mugiliformes: Mugilidae) from Jeju Island, Korea. Korean J Ichthyol 24, 135-138.

Kwun HJ, Kim JK and Kweon SM. 2012b. First record of bluespot mul- 
let, Moolgarda seheli (Mugiliformes: Mugilidae) from Jeju Island, Korea. J Korean Ichthyol 24, 297-301.

Linnaeus C. 1758. Systema Naturae per Regna Tria Naturae, Secundun Classes, Ordines, Genera, Species, cum Characteribus, Differentiis, Synonymis, Locis. 10th ed. Tomus I. Editio Decimal, Reformata. Laurentii Salvii, Holmiae, Stockholm, SE.

Mori T. 1952. Check list of the fishes of Korea. Mem Hyogo Univ Agric $1,1-228$.

Motomura H, Kuriiwa K, Katayama E, Senou H, Ogihara G, Meguro M, Matsunuma M, Takata Y, Yoshida T, Yamashita M, Kimura S, Endo H, Murase A, Iwatsuki Y, Sakurai Y, Harazaki S, Hidaka K, Izumi H and Matsuura K. 2010. Annotated checklist of marine and estuarine fishes of Yaku-shima Island, Kagoshima, southern Japan. In: Fishes of Yaku-shima Island. Motomura H and Matsuura K, eds. National Museum of Nature and Science, Tokyo, JP, pp. 65-247.

Nelson JS. 2006. Fishes of the World. 4th ed. John Wiley \& Sons, Inc., Hoboken, NJ, US.

Palumbi SR. 1996. Nucleic acids II: the polymerase chain reaction. In: Molecular Systematics. Hillis DM, Moritz C and Mable BK, eds. Sinauer Associates Inc., Sunderland, MA, US, pp. 205-247.

Quoy JRC and Gaimard JP. 1824-1825. Description des poisons. Chapter IX. In: de, Voyage Autour du Monde Exécuté sur les Corvettes de L. M. "L'Uranie" et "La Physicienne," Pendant les Années 1817, 1818, 1819 et 1820. Freycinet L, ed. Paris, FR, pp. 192-401.

Randall JE and Lim KKP. 2000. A checklist of the fishes of the south China Sea. Raffles Bull Zool Suppl 8, 569-667.

Schultz LP, Herald ES, Lachner EA, Welander AD and Woods LP. 1953. Fishes of the Marshall and Marianas islands. Vol. I. Families from Asymmetrontidae through Siganidae. Bull U S Natl Mus 202, $1-685$.

Seale A. 1910. New species of Philippine fishes. Philipp J Sci 4, 491543.

Senou H. 2002. Mugilidae. In: Fishes of Japan with Pictorial Keys to the Species. Nakabo T, ed. Tokai University Press, Tokyo, JP, pp.
$537-541$

Shen SC. 2001. Mugilidae. In: Fishes of Taiwan. Revised ed. Shen SC, ed. National Taiwan University Press, Taipei, TW, pp. 437-442.

Smith A. 1837-1847. Illustrations of the Zoology of South Africa; Consisting Chiefly of Figures and Descriptions of the Objects of Natural History Collected during an Expedition into the Interior of South Africa in the Years 1834, 1835, and 1836; Fitted out by "The Cape of Good Hope Association for Exploring central Africa": Together with a Summary of African Zoology, and an Inquiry into the Geographical Ranges of Species in that Quarter of the Globe. Vol. 4. Smith, Elder and Co., London, GB.

Tamura K, Peterson D, Peterson N, Stecher G, Nei M and Kumar S. 2011. MEGA5: molecular evolutionary genetics analysis using maximum likelihood, evolutionary distance, and maximum parsimony methods. Mol Biol Evol 28, 2731-2739.

Temminck CJ and Schlegel H. 1845. Pisces part 7-9. In: Fauna Japonica, sive Descriptio Animalium Quae in Itinere per Japoniam Suscepto Annis 1823-30 Collegit, Notis Observationibus et Adumbrationibus Illustravit P. F. de Siebold. A. Arnz and Co., Leiden, NL, pp. 113-172.

Thompson JD, Higgins DG and Gibson TJ. 1994. CLUSTAL W: improving the sensitivity of progressive multiple sequence alignment through sequence weighting, position-specific gap penalties and weight matrix choice. Nucleic Acids Res 22, 4673-4680.

Thomson JM. 1997. The Mugilidae of the world. Mem Qld Mus 41, 457-562.

Vandersea MW, Litaker RW, Marancik KE, Hare JA, Walsh HJ, Lem S, West MA, Wyanski DM, Laban EH and Tester PA. 2008. Identification of larvae sea basses (Centropristis spp.) using ribosomal DNA-specific molecular assays. Fish Bull 106, 183-193.

Victor BC, Hanner R, Shivji M and Hyde J. 2009. Identification of the larval and juvenile stages of the cubera snapper, Lutjanus cyanopterus, using DNA barcoding. Zootaxa 2215, 24-36.

Whitley GP. 1930. Five new generic names for Australian fishes. Aust Zool 6, 250-251. 